\title{
Introduction to the Special Issue: Rethinking Social Studies in a Post-truth Era
}

\author{
David Scott \\ Werklund School of Education \\ University of Calgary \\ scottd@ucalgary.ca \\ Cathryn van Kessel \\ Department of Secondary Education \\ University of Alberta \\ vankesse@ualberta.ca
}

The triumph of Trump and the ongoing popularity of far right parties across the world have brought into question basic liberal democratic values of a free press, the rule of law, and notions of truth. Reflecting these developments, in 2016 the Oxford Dictionary (2016) recognized "post-truth," as the word of the year. Pointing to an emergent political landscape where "objective facts are less influential in shaping public opinion than appeals to emotion and personal belief" (Oxford Dictionary, 2016, para. 1), the March 2017 cover of Time Magazine equally asked: Is Truth Dead?

The implications of these developments for social studies and education more generally are profound. In a recent article entitled History Educators in a New Era, Dr. Peter Seixas (2017) from the University of British Columbia, asserted: "This is a dangerous moment, globally, for the liberal arts, education and research, for democratic values generally, and for history and history education specifically" (para .1). He went on to argue that liberal democratic traditions have increasingly come under attack across the Western world. Populist political agitators like President Donald Trump now present 'alternative facts' to describe provable falsehoods. This trend has led many social studies educators to reconsider what our role should be within this era of alternative facts.

Responding to this question, Seixas offers two key pieces of guidance. The first concerns a renewed attentiveness to the historical narratives we teach to our students. In this regard, he challenges the singular focus of many University professors and historians on the flaws and problems with traditional narratives, and the need to examine the dark side of our national past. In the Canadian context, this has included the ways official government policies, aided by popular public support, served to perpetuate racial segregation in schools, the forced assimilation of Indigenous peoples, racialized immigration restrictions, anti-Semitism, the mistreatment of Chinese immigrant railway workers, and the displacement and internment of Japanese Canadians (See: Lund, 2006, p. 38). In order to counter the alt right's apocalyptic view of the world, in place of a focus on such stories, Seixas argues for a new appreciation for a qualified narrative of progressive opportunity and open democracy, which has historically been central to the social studies classroom. He writes:

This does not mean shuffling systemic racism, colonialism, homophobia, and gender inequality back into obscurity, much less silence, but it does call for 
remembering the promises and obligations of democratic rule ... and the moral virtues and qualities of character that enable both good leadership and active participation in a democratic state. (Seixas, 2017, para. 7)

Seixas also asks educators to reconsider the problem of historical interpretations. With the rise of the disciplinary movement in history education, many educators have sought to help students question the stories told in textbooks. While acknowledging the credibility of such sources, educators have worked to help students appreciate that what they are reading is only one interpretation of 'what happened' in the past, as many other historical accounts are equally valid .

Seixas continues to see this work as central to social studies and history education, but he additionally argues, that we also need to help students "understand the limits of interpretation, the constraints that bind what we say to the evidence that we have, and the importance of defending interpretations that are supported by the weight of evidence" (para. 5). In making this claim, Seixas challenges educators to move beyond giving credence to a wide range of interpretations on the past, while refusing to advocate for any single one. Some interpretations of the past are clearly better than others, and there is a need to make this clear to our students.

Yet, despite these important and insightful comments, Seixas (2017) also went on to attack poststructuralism: "Academics hardly needed to rally to defend the idea of truth because the only threat was from some of our own poststructuralist provocateurs, delivered in prose so tortured that it had little apparent impact on the broader public sphere" (para. 2). On this point we disagree. The emergence of a post truth era opens up many important questions that poststructuralism, as well as a range of other critical discourses, can help us think through, particularly those related to the assumptions dominant narratives might make, including the Enlightenment ideals of the existence of a single Truth. Drawing on critical, hermeneutic, and Indigenous insights in education, in this special issue a range of curriculum scholars weigh in on the nature of truth and posttruth in relation to education specifically, as well as our situations as humans more generally.

In the opening article, Debbie Sonu considers how hyper individualism at the expense of interconnectedness has contributed to the problems of our post-truth times, including the public and political normalization of white nationalism and authoritarian leadership. In this regard, she asks us to consider how truth has always been contested, and yet how the dangers arising from our current neoliberal rationality are particularly troubling in terms of the disintegration of the social.

In the subsequent article, Kent den Heyer, taking up Seixas' work directly, asks: What post-truth? Pointing to a liberal nostalgia narrative that has never taken white supremacy, imperialism, and patriarchy seriously, he highlights the dangers of returning to an (idealized) past that leaves marginalized groups with a single option- to join or be forgotten (as elaborated by Vicki Bouvier in this issue). While power always controls opinion, including what does and does not constitute personal, political or disciplinary legitimacy, people have always and do possess the capacity to articulate something more nourishing for "becoming subjects" to our learning and lives. 
Vicki Bouvier, in the third article of this special issue, calls upon us to wonder: When did truth become a noun, something we own, and not a verb - an action-oriented process situated within both an individual and collective orientation? Is the notion of "post-truth" a mask for the continued colonization of already subjugated, marginalized, and erased truths? There is a lot at stake in these discussions of truths and post-truths. Thinking via the concept of the wetiko disease, we are invited to consider "truthing" as a way to (re)consider our ethical relations.

In the final article, James Field considers that truth perhaps has ceased to maintain order, establish commitments, and provide us with purpose. Given this state of affairs, he asks us to consider what are our obligations to the other, if I am not called by the truth? What happens to our relations with others, if they are not founded on notions of "being true to one another"? Is the capital "T" in "Truth and Reconciliation" a spelling mistake? Perhaps the question ought to become: How we might bring truth back to life, but ensure that these truths are fed and fortified with love?

The four scholars in this special issue open up vital discussions about truths. What are the possibilities for a social studies curriculum that heals us conceptually, ethically, pedagogically at a time when all our beliefs and values, in community and culture, are being unsettled and tested? As we approach social studies in our classrooms and "the social" more generally, these authors call on us to put careful thought and action into how we, as human beings, want to live together with others.

\section{References}

Lund, D. (2006). Waking up the neighbors: Surveying multicultural and antiracist education in Canada, the United Kingdom, and the United States. Multicultural Perspectives: The Official Journal of the National Association for Multicultural Education, 8(1), 35-43. Retrieved from https://www.ucalgary.ca/dlund/files/dlund/wakingneighbours-lund-mp06.pdf

Oxford Dictionary. (2016). Post-truth. Retrieved from https://en.oxforddictionaries.com/word-of-the-year/word-of-the-year-2016

Seixas, P. (2017). History educators in a new era. Public History Weekly. Retrieved from https://public-history-weekly.degruyter.com/5-2017-20/history-educators-in-a-newera/ 